\title{
The Role of Proximal Tubular Cells in the Early Stages of Diabetic Nephropathy
}

\author{
Giovani B Peres and Yara M Michelacci*
}

Department of Biochemistry, Escola Paulista de Medicina, Unifesp, São Paulo, SP, Brazil

\begin{abstract}
The present paper reviews the role of proximal tubular cells in the early stages of diabetic nephropathy. The chronic hyperglycemia that occurs in diabetes mellitus may have different effects on different cells, and some kidney cell types may be injured earlier than others. Recent findings point towards a relevant involvement of proximal tubular cells in the early stages of diabetic nephropathy. As normal urine contains very low amounts of proteins, while proteinuria occurs in kidney diseases, it was believed that the glomerular filtration barrier was capable of preventing the passage of proteins. Nevertheless, recent data indicate that the primary filtrate does contain albumin and other proteins, which possibly are reabsorbed by tubular cells. So, the increased albuminuria that occurs in diabetic nephropathy and other renal diseases could result, at least in their early stages, from defective tubular processing. The participation in this process of the receptors megalin, cubilin, and the newborn Fc receptor (FcRn) is discussed, regarding both protein transcytosis and lysosomal digestion. The processing and urinary excretions of sulfated polysaccharides are also briefly considered.
\end{abstract}

Keywords: Proximal tubular cells; Diabetes mellitus; Diabetic nephropathy; Lysosomal enzymes; Albumin receptors

\section{Introduction}

Diabetes mellitus (DM) is a metabolic disease of multiple etiologies, characterized by chronic hyperglycemia. It is estimated that 347 million people worldwide have DM [1], and the main diabetic complications arise from macro- and microangiopathies. Macroangiopathies are characterized by narrowing of arterial lumen throughout the body, mostly due to atherosclerosis, leading to coronary, cerebrovascular, and peripheral complications [2]. Microangiopathies, characterized by loss of normal function of capillary bed and thickening of basement membranes, lead to retinopathy, neuropathy, and diabetic nephropathy [3].

Diabetic nephropathy affects approximately one third of the diabetic patients [4], and is the most common cause of end-stage renal disease [5]. An early marker of any nephropathy is microalbuminuria, which may progress to overt proteinuria, if not adequately treated [6]. The initial stages of diabetic nephropathy are usually associated to glomerular capillar dysfunction, increased perfusion and hyperfiltration [7]. These hemodynamic alterations, together with changes in the glomerular permselectivity barrier, could lead to albumin leakage from the glomerular capillary to the Bowman's capsule [8]. This traditionally accepted idea could justify the albuminuria observed in patients with diabetic nephropathy, assuming that albumin remains intact through the renal passage. However, there are evidences indicating that it is not always so [9]. For instance, there are solid evidences that albumin is, at least in part, degraded during its renal transit $[10,11]$, suggesting the participation of other renal cells, such as podocytes and tubular cells, in the handling of proteins and other macromolecules.

The present review focused the evidences that support the participation of tubular cells in the renal handling and urinary excretion of proteins, especially albumin, in the early stages of diabetic nephropathy. The processing and urinary excretions of sulfated polysaccharides are also briefly considered.

\section{Glomerular Structure and Function}

The glomerulus is the filtration unit of the kidney. Human kidneys generate a primary filtrate of about $180 \mathrm{~L}$ from the approximately 900 $\mathrm{L}$ of blood that passthrough them on a daily basis. Nevertheless, due to reabsorption of water and solutes by the tubular epithelial cells of the kidney, this primary filtrate is concentrated to a urinary output of only 1-2 L. The glomerular filtration barrier, which lies between the vasculature and the urinary space, retards the passage of plasma proteins, while ensuring the efficient flow of water and small solutes that comprise the primary filtrate.

The glomerular filtration barrier is a three-layered structure that lies between the vasculature and Bowman's space, composed by an endothelial cell layer, the glomerular basement membrane (GBM), and an epithelial cell layer (podocytes). Within the glomerulus, it is the only separation between the bloodstream and the urine.

Podocytes, the glomerular visceral epithelial cells, are morphologically complex cells that reside within the urinary space (or Bowman's space), and are bathed in the primary urine. Podocytes enwrap the outer surface of the glomerular capillaries by extending narrow foot processes that interdigitate with those of adjacent podocytes. Juxtaposed foot processes are directly linked to one another by the glomerular slit diaphragms.

On the blood side, glomerular capillaries are lined by endothelial cells that bear many fenestrations, which are "holes" that allow the passage of fluid across the cell layer. Ultrastructural analyses have shown that some of these fenestrations have wagon wheellike diaphragms, while others contain a filamentous plug, possibly composed by glycocalyx.

*Corresponding author: Yara M Michelacci, Department of Biochemistry Escola Paulista de Medicina, Unifesp, Rua Tres de Maio, 100 04044-020 - São Paulo, SP, Brazil, Tel: 55-11-5576-4438, extn 1187; Fax: 55-11-5573-6407 E-mail: yara.bioq@epm.br

Received April 23, 2015; Accepted May 15, 2015; Published May 20, 2015

Citation: Peres GB, Michelacci YM (2015) The Role of Proximal Tubular Cells in the Early Stages of Diabetic Nephropathy. J Diabetes Metab 6: 551. doi:10.4172/21556156.1000551

Copyright: @ 2015 Peres GB, et al. This is an open-access article distributed unde the terms of the Creative Commons Attribution License, which permits unrestricted use, distribution, and reproduction in any medium, provided the original author and source are credited. 
Citation: Peres GB, Michelacci YM (2015) The Role of Proximal Tubular Cells in the Early Stages of Diabetic Nephropathy. J Diabetes Metab 6: 551. doi:10.4172/2155-6156.1000551

Page 2 of 6

The GBM is a specialized extracellular matrix situated between the podocytes and endothelial cells. Both cell types are important for maintaining the GBM's structure and function $[12,13]$. The GBM has three layers when viewed by transmission electron microscopy: a central electron-dense lamina, flanked by two light layers. It is unusually thick compared to most other basement membranes, and although formed by laminin, type IV collagen, nidogen and heparan sulfate proteoglycan [14], as other basement membranes, the isoforms present in the GBM are very different from those of other basement membranes. The GBM occupies a prime position in the glomerular filtration barrier.

In the center of the glomerulus is the mesangium, composed by mesangial cells and the mesangial extracellular matrix. The mesangium provides support for the capillary loops and modulates glomerular filtration through the smooth muscle-like activity of mesangial cells [15]. Mesangial cell proliferation and mesangial matrix expansion seem to be regulated by cytokines, and occur in many glomerular diseases [16].

\section{Morphological Changes in Diabetic Kidney}

Although hyperglycemia and its consequences may affect each kidney cell, not all of them present signs of injury at the same time. For instance, in diabetic rats, we have recently shown distended proximal tubules, with thinner walls and reduced brush borders, before any changes in glomerular morphology [17] (Figure 1). This was also observed by others $[18,19]$, and electron microscopy has shown swollen and bulbous microvilli in diabetic nephropathy [20]. Furthermore, thickening of proximal tubular basement membrane was also reported [21].

Glomerular changes have also been described, including mesangial cell proliferation and hypertrophy, expansion of mesangial extracellular matrix, and thickening of GBM, eventually leading to nodular glomerulosclerosis (Kimmelstiel-Wilson nodules) [22,23]. Mesangial cells isolated from diabetic rats synthesize and secrete increased amounts of extracellular matrix proteoglycans in culture, but similar effects are not induced by high glucose only [24]. Nevertheless, it seems that the basement membrane thickening and mesangial expansion
NL

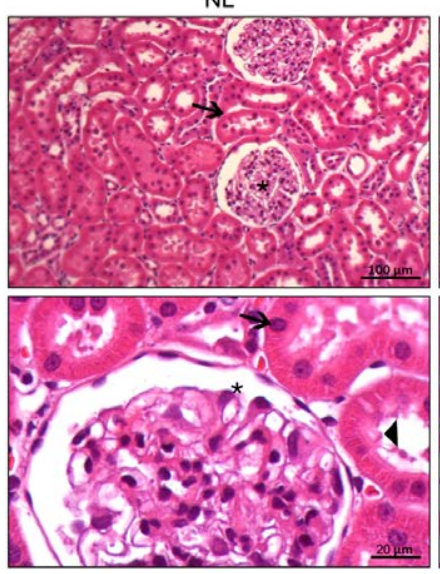

DM

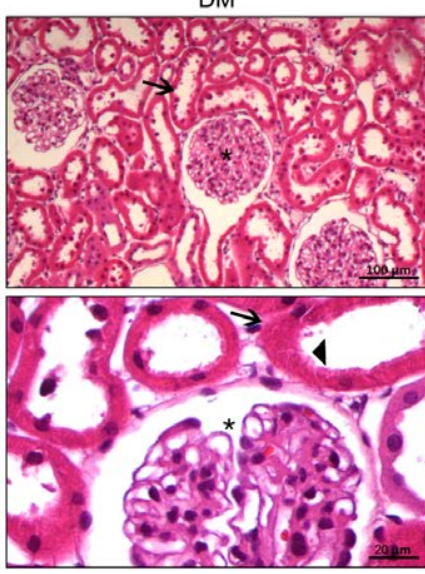

Figure 1: Optical microscopy of diabetic (DM) and normal (NL) rat kidneys. Kidneys from normal and diabetic rats (30 days of DM) were stained in hematoxylin and eosin. Low magnification images (bars $=100 \mu \mathrm{m}$ ) show cortical region with convoluted tubules (arrows) and glomeruli $\left(^{*}\right)$. In DM higher magnification images (bars $=20 \mu \mathrm{m}$ ), it is possible to evidence proximal tubules with thinner walls (arrows) and reduced brush borders (arrow heads). No changes were observed in glomeruli. precede symptoms of renal dysfunction [25], but occur after tubular alterations, suggesting that the tubular injury is not triggered by the changes in glomerular physiology. It is possible that the proximal tubular cells are the most prone to the high glucose-induced damage, but this hypothesis remains to be proved.

Interstitial fibrosis occurs even latter, in which tubular cells suffer epithelial-to-mesenchymal transition, presenting a fibroblastic-like phenotype and extracellular matrix deposition [26,27].

In humans, a few years after diabetes onset, vascular thickening and hyalinization with effacement of the endothelia, was also observed $[23,28]$.

\section{Excretion of Proteins in Diabetic Nephropathy}

Traditionally, the glomerular filtration barrier was considered to be a sophisticated filter that permits water and plasma solutes to pass into the Bowman's capsule space, preventing larger molecules from being filtered. These would be selected by their size, shape, and charge [29]. It was believed that the glomerular filtrate was essentially albumin-free, but recent studies reported that the glomerular filtrate does contain albumin. This indicates that albumin is able to cross the GBM, as well as the fenestrated endothelial and the epithelial cell layers. Concerning podocytes, albumin could either cross the paracellular slit diaphragms, or pass through the podocytes themselves. Analysis of the podocyte slit diaphragm using high-resolution electron-tomography [30] showed that the filtration slit has convoluted strands that form zipper-like sheets with pores as big as the diameter of albumin, with direct involvement of the transmembrane protein nephrin [31]. More recently, it was reported that podocytes internalize albumin along the basal membrane via caveolin-mediated (but not clathrin-mediated) vesicular transport [32], indicating that both pathways are possible.

By the use of intravital microscopy and fluorescent albumin, Russo et al. [33] have shown that the renal filtration of albumin in normal rats is almost 50 times the values previously reported, obtained by micropuncture [34]. As the albumin concentration in normal urine is very low, it seems that there is a retrieval pathway, possibly in proximal tubular cells $[33,35]$. Receptor-mediated endocytosis, involving the complex megalin/cubilin [36,37], as well as the neonatal Fc receptor (FcRn) [38,39] seem to be involved [40]. Internalized albumin may either be retrieved back to circulation via transcytosis or follow lysosomal degradation, with fragments being exocytosed back into tubular lumen and excreted in urine [41,42].

Megalin is a $600 \mathrm{kDa}$ transmembrane glycoprotein that can bind a variety of ligands [43], including albumin, vitamin-binding proteins, carrier proteins, lipoproteins, hormones, drugs, enzymes, and immunerelated proteins. Megalin can also act as a membrane anchor for cubilin, a cell surface $460 \mathrm{kDa}$ glycoprotein, which shows no apparent transmembrane domain and no GPI anchor. In proximal tubular cells, the two proteins form a complex that works as a scavenger receptor, and is the major receptor for renal albumin reabsortion [43]. It was reported that megalin and cubilin are among the 20 most abundant proteins in the urine of type $1 \mathrm{DM}$ microalbuminuric patients [44]. So, the shedding of this complex from proximal tubular apical membrane into the urine may also contribute to the increased excretion of intact albumin in diabetic urine. Apparently, the ectodomain of megalin is shed by a protein kinase C-regulated metalloprotease [45]. This receptor shedding leaves, in proximal tubular cell membrane, the megalin transmembrane and endo-domains. This activates a Notchlike signaling pathway [46], which controls the expression of brush 
Citation: Peres GB, Michelacci YM (2015) The Role of Proximal Tubular Cells in the Early Stages of Diabetic Nephropathy. J Diabetes Metab 6: 551. doi:10.4172/2155-6156.1000551

Page 3 of 6

border-related genes, and directly influence the absorptive capacity of proximal tubular cells.

There are evidences that transforming growth factor- $\beta$ (TGF- $\beta$ ) is upregulated in diabetic nephropathy and other renal diseases [47]. Increased TGF- $\beta$ signaling reduces the expression of megalin/cubilin, and thus slows down albumin internalization [48]. This effect is dependent on transcription factors Smad2 and Smad3.

Changes in tubular cell morphology, especially concerning microvilli, which could directly affect protein reabsortion by proximal tubular cells, may be related to cytoskeleton alterations. In fact, it was shown that disruption of actin and microtubule cytoskeleton reduces albumin uptake. This is not surprising, since the initial phases of receptor-mediated endocytosis depend on intact actin, whereas latter phases are supported by microtubules [49].

The neonatal $\mathrm{Fc}$ receptor $(\mathrm{FcRn})$ received its name because it transports maternal IgG through the placenta and the fetal small intestine, to passively immunize the fetus [50]. FcRn is a heterodimer consisting of a MHC class I-like heavy chain and a a2-microglobulin light chain [51]. It is widely expressed in adult cells, including endothelial cells [52], hepatocytes [53], spleen, lung, and kidney $[54,55]$. These findings suggest that IgG is not the only ligand of FcRn. In the kidney, FcRn is expressed on the surface of podocytes and in the brush border of the proximal tubular cells [54]. FcRn binds albumin (and also $\operatorname{IgG}$ ) in a $\mathrm{pH}$-dependent manner, with higher affinity at acidic $\mathrm{pHs}(<6.5)$, and lower at $\mathrm{pH} \sim 7.4[56,57]$. This property is very important because it renders $\mathrm{FcRn}$ capable to rescuing IgG and albumin from acidic endosomes, preventing their lysosomal degradation, and increasing their lifespans $[58,59]$. Recently, it was proposed that FcRn is involved in an important trancytosis retrieval mechanism of albumin in proximal tubular cells [60,61], although luminal $\mathrm{pH}$ does not favor albumin binding to FcRn [62]. Therefore, it is proposed that the megalin/cubilin complex binds albumin at the cell surface, while $\mathrm{FcRn}$ binds albumin in the endosomes, at low $\mathrm{pH}$. Vesicles containing FcRn-linked albumin fuse to the basolateral membrane, releasing the ligand, while free albumin is digested by the lysosomal pathway. Figure 2 shows a schematic representation of this hypothesis.

\section{Degradation of Internalized Proteins: Lysosomal Enzymes in Diabetic Kidney}

Methods traditionally used for detection of albumin in urine, such as radioimmune assay (RIA) and immunoprecipitation, are not able to detect albumin-derived small peptides [10]. In patients with diabetic nephropathy, which show high urinary albumin, as measured by RIA, it was shown that the kidney fragmentation ratio of albumin, expressed as urinary fragmented/intact albumin, is decreased in comparison to normal subjects [63]. Figure 3 shows a gel permeation chromatography of urinary proteins from diabetic (30 days) and normal rats. It is clear that normal rats excrete low amounts of high molecular weight proteins, in contrast to diabetic rats that excrete higher amounts of high molecular weight proteins in the urine [17].

Back in the 1990's, Olbricht and Geissinger [64] proposed a role for lysosomal proteolytic enzymes in diabetic renal hypertrophy, and reported decreased activities of cathepsin B and cathepsin L in proximal tubules of streptozotocin-DM rats on the 4th day of diabetes. These activities were equal to controls six months later, when end stage renal hypertrophy had already occurred. Decreased tubular cathepsins were also reported on the 2nd day of DM [65].
We have recently reported decreased expression and activities of lysosomal proteases, especially cathepsins B and L, in kidney during the early stages of DM (10 and 30 days) [17]. Immunohistochemistry localized most of the kidney cathepsin B at the brush border of proximal

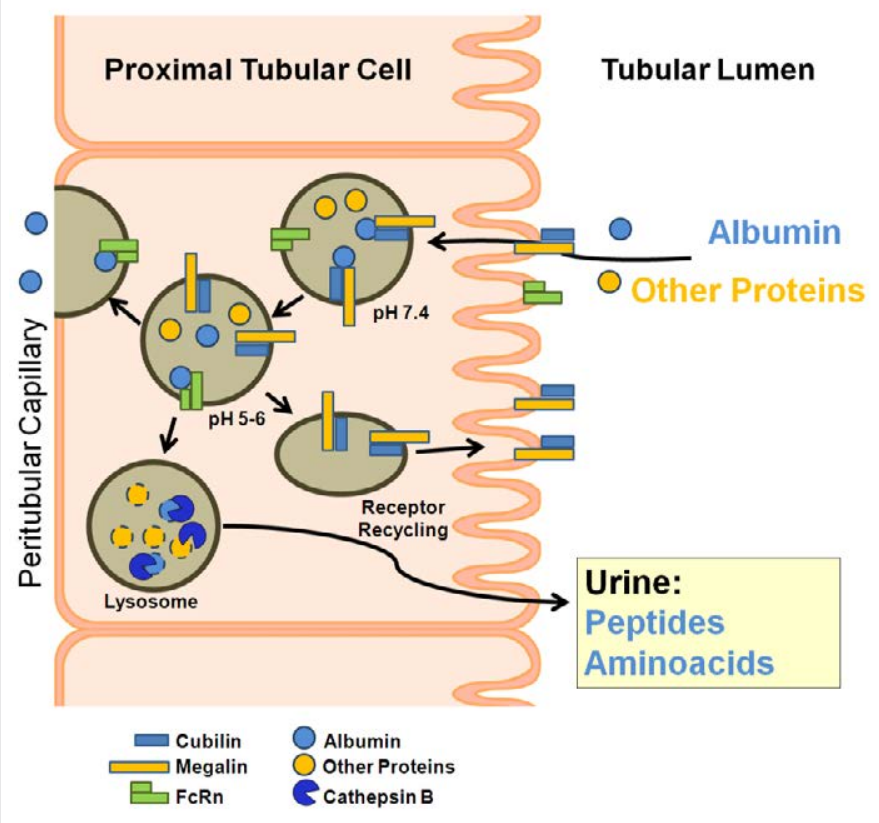

Figure 2: Hypothetical scheme showing the proximal tubular handling of albumin and other proteins. Albumin (blue) and other proteins (yellow), after binding to megalin/cubilin complex on the brush border of proximal tubular cells, are internalized, via clathrin-coated vesicles, that fuse to early endosomes. Acidification of these endosomes causes dissociation of albumin from the megalin/cubilin complex, but, at $\mathrm{pH} 5-6$, albumin binds to FcRn, and undergoes transcytosis. The megalin/cubilin complex is recycled to the apical brushborder membrane, while unbound albumin and other proteins are transferred to lysosomes for degradation by cathepsin B and other lysosomal proteases. Degradation products are exocytosed into the tubular lumen, and excreted in the urine.

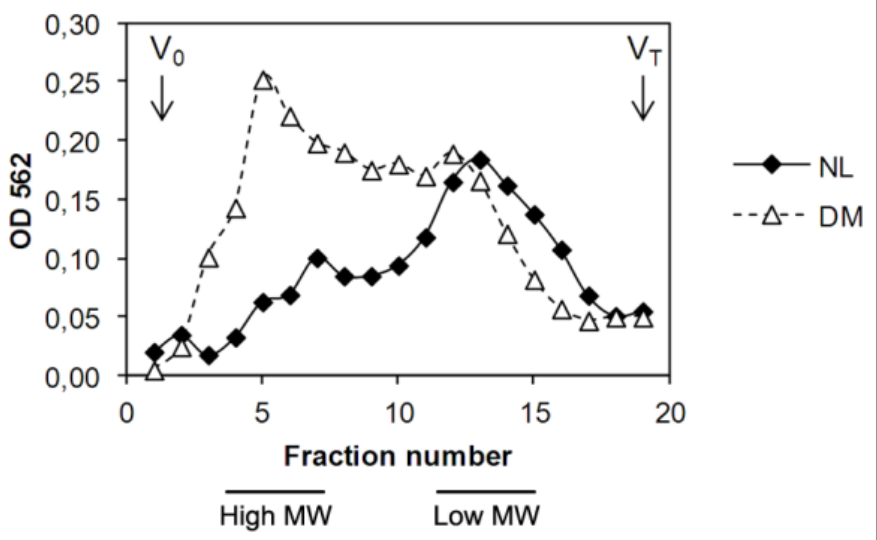

Figure 3: Gel permeation chromatography of urinary proteins from normal (NL) and diabetic (DM) rats. Urine samples $(0.5 \mathrm{ml}$ for normal, and $3 \mathrm{ml}$ for diabeticrats) were concentrated to $0.4 \mathrm{ml}$, and applied to a Sephadex G-100 Superfine column $(1 \times 30 \mathrm{~cm})$, equilibrated and eluted with phosphate buffer saline. Fractions $(0.72 \mathrm{ml})$ were eluted at a constant flow rate $(0.12 \mathrm{ml}$ min). Protein was measured by a modified Lowry method, with bicinchoninic acid (OD 562)(Brown RE, Jarvis KL, Hyland KJ (1989) Protein measurement using bicinchoninic acid: elimination of interfering substances. Anal Biochem 180: 136-139). 
Citation: Peres GB, Michelacci YM (2015) The Role of Proximal Tubular Cells in the Early Stages of Diabetic Nephropathy. J Diabetes Metab 6: 551. doi:10.4172/2155-6156.1000551

tubules, which were clearly affected by the disease (thinner walls with reduced brush borders).

There are evidences that lysosomal enzymes are affected by increased TGF- $\beta[66,67]$, although the signaling pathway is unknown. As already mentioned, TGF- $\beta$ is upregulated in diabetic nephropathy and other renal diseases. In the glomerulus, TGF- $\beta$ regulates the synthesis of extracellular matrix macromolecules, including collagens, fibronectin, tenascin, and proteoglycans, as well as integrins that are the receptors for some of these molecules. Several DM changes, such as sustained hyperglycemia, advanced glycation end products (AGEs), generation of reactive oxygen species (ROS), and increased activity of protein kinase $\mathrm{C}(\mathrm{PKC})$, may contribute to increased TGF- $\beta$ signaling [22].

\section{Aberrant Excretion of Sulfated Polysaccharides}

Other aberrant renal processing in diabetic nephropathy concerns sulfated polysaccharides. A marked decrease in the urinary excretion of glycosaminoglycans was reported in streptozotocin-DM in rats $[68,69]$. Decreased urinary excretion of glycosaminoglycans was also reported in other renal diseases $[25,70]$. DM rats have also shown decreased excretion of exogenous dextran sulfates of different molecular weights [71]. Higher amounts of dextran sulfates, especially those of high molecular weights, accumulated in diabetic kidney and liver, suggesting cell internalization and accumulation of these macromolecules. In contrast to the urine, the total kidney glycosaminoglycans increased in DM kidney, because of chondroitin sulfate and dermatan sulfate accumulation [68], possibly due to a lower digestion rate in comparisons to normal rats [17].

Although increased urinary excretion of glycosaminoglycans have been reported in DM [72,73], most of these studies used methods which were shown to be non-reliable to measure urinary glycosaminoglycans $[74,75]$. Reliable data are obtained by purification of urinary glycosaminoglycans by dialysis [75], gel permeation or ion exchange chromatography [74], and analysis by a combination of agarose gel electrophoresis [76] and enzymatic degradation with specific glycosaminoglycan lyases [77].

Decreased activities of glycosidases were also reported in diabetic kidney, with the presence of metachromatic staining by toluidine blue in tubular cells [17]. The decreased activity of glycosidases could lead to intracellular accumulation of partially digested macromolecules, contributing to decreased levels of sulfated polysaccharides in the urine. Also, these engorged endosomes could impair normal tubular cell function.

\section{Conclusion}

Since the amounts of intact proteins in normal urine are low, it is a common thought that proteins are unable to cross the glomerular filtration barrier. Recent findings, however, point towards the opposite way, as newer methodologies have shown that albumin is indeed present in the normal glomerular ultrafiltrate, indicating that this protein crosses the glomerular barrier. Later on, this protein is retrieved by tubular cells, through receptor-mediated endocytosis, and is either sent back to the circulation via transcytosis, or digested by lysosomal enzymes. The digestion products are excreted into the urine. In diabetic nephropathy, the changes in proximal tubular cells appear to be triggered earlier than those that occur in other cell types. The loss of scavenger receptors and/or the decrease in lysosomal proteases could contribute to the increased amounts of intact proteins in the urine of DM subjects (as detected by RIA). Concerning sulfated polysaccharides, decreased tubular glycosidases could lead to intracellular accumulation of partially digested macromolecules, contributing to the decreased levels of these compounds in the urine, and impairment of normal tubular function.

\section{References}

1. Danaei G, Finucane MM, Lu Y, Singh GM, Cowan MJ, et al. (2011) National, regional, and global trends in fasting plasma glucose and diabetes prevalence since 1980: systematic analysis of health examination surveys and epidemiological studies with 370 country-years and $2 \cdot 7$ million participants. Lancet 378: 31-40.

2. Fowler MJ (2008) Microvascular and Macrovascular Complications of Diabetes Clinical Diabetes 26: 77-82.

3. The Diabetes Control and Complications Trial Research Group (1993) The effect of intensive treatment on the development and progression of long-term complications in insulin-dependent diabetes mellitus. N Engl J Med 329: 977 986

4. Reutens AT, Atkins RC (2011) Epidemiology of diabetic nephropathy. Contrib Nephrol 170: 1-7.

5. Molitch ME, DeFronzo RA, Franz MJ, Keane WF, Mogensen CE, et al. (2004) Nephropathy in diabetes. Diabetes Care 27 Suppl 1: S79-83.

6. Gilbert RE, Cooper ME, McNally PG, O'Brien RC, Taft J, et al. (1994) Microalbuminuria: prognostic and therapeutic implications in diabetes mellitus. Diabet Med 11: 636-645

7. Hostetter TH (2003) Hyperfiltration and glomerulosclerosis. Semin Nephrol 23 194-199.

8. Myers BD, Winetz JA, Chui F, Michaels AS (1982) Mechanisms of proteinuria in diabetic nephropathy: a study of glomerular barrier function. Kidney Int 21 633-641.

9. Greive KA, Nikolic-Paterson DJ, Guimaraes MA, Nikolovski J, Pratt LM, et al (2001) Glomerular permselectivity factors are not responsible for the increase in fractional clearance of albumin in rat glomerulonephritis. Am J Pathol 159 : 1159-1170.

10. Osicka TM, Panagiotopoulos S, Jerums G, Comper WD (1997) Fractional clearance of albumin is influenced by its degradation during renal passage. Clin Sci (Lond) 93: 557-564.

11. Burne MJ, Osicka TM, Comper WD (1999) Fractional clearance of high molecular weight proteins in conscious rats using a continuous infusion method. Kidney Int 55: 261-270.

12. Miner JH (2011) Organogenesis of the kidney glomerulus: focus on the glomerular basement membrane. Organogenesis 7: 75-82.

13. Levidiotis V, Power DA (2005) New insights into the molecular biology of the glomerular filtration barrier and associated disease. Nephrology (Carlton) 10 157-166.

14. Miner JH (2012) The glomerular basement membrane. Exp Cell Res 318: 973 978

15. Schlöndorff D, Banas B (2009) The mesangial cell revisited: no cell is an island J Am Soc Nephrol 20: 1179-1187.

16. Floege J, Eng E, Young BA, Alpers CE, Barrett TB, et al. (1993) Infusion of platelet-derived growth factor or basic fibroblast growth factor induces selective glomerular mesangial cell proliferation and matrix accumulation in rats. $\mathrm{J}$ Clin Invest 92: 2952-2962.

17. Peres GB, Juliano MA, Simões MJ, Michelacci YM (2013) Lysosomal enzymes are decreased in the kidney of diabetic rats. Biochim Biophys Acta 1832: 85-95.

18. Omara EA, Nada SA, Farrag AR, Sharaf WM, El-Toumy SA (2012) Therapeutic effect of Acacia nilotica pods extract on streptozotocin induced diabetic nephropathy in rat. Phytomedicine 19: 1059-1067.

19. Elbe H, Vardi N, Esrefoglu M, Ates B, Yologlu S, et al (2015) Amelioration of streptozotocin-induced diabetic nephropathy by melatonin, quercetin, and resveratrol in rats. Hum Exp Toxicol 34: 100-113

20. Akimoto Y, Miura Y, Toda T, Wolfert MA, Wells L, et al. (2011) Morphological changes in diabetic kidney are associated with increased O-GlcNAcylation of cytoskeletal proteins including alpha-actinin 4. Clin Proteomics 8: 15.

21. Brito PL, Fioretto P, Drummond K, Kim Y, Steffes MW, et al. (1998) Proxima 
Citation: Peres GB, Michelacci YM (2015) The Role of Proximal Tubular Cells in the Early Stages of Diabetic Nephropathy. J Diabetes Metab 6: 551. doi:10.4172/2155-6156.1000551

Page 5 of 6

tubular basement membrane width in insulin-dependent diabetes mellitus. Kidney Int 53: 754-761.

22. Kanwar YS, Sun L, Xie P, Liu FY, Chen S (2011) A glimpse of various pathogenetic mechanisms of diabetic nephropathy. Annu Rev Pathol 6: 395423.

23. Fioretto P, Mauer M (2007) Histopathology of diabetic nephropathy. Semin Nephrol 27: 195-207.

24. Hadad SJ, Michelacci YM, Schor N (1996) Proteoglycans and glycosaminoglycans synthesized in vitro by mesangial cells from normal and diabetic rats. Biochim Biophys Acta 1290: 18-28.

25. Michelacci YM, Cadaval RA, Rovigatti RM, Kohlman O (2001) Renal and urinary glycosaminoglycans in an experimental model of chronic renal failure in rats. Exp Nephrol 9: 40-48.

26. Nangaku M (2004) Mechanisms of tubulointerstitial injury in the kidney: final common pathways to end-stage renal failure. Intern Med 43: 9-17.

27. Zavadil J, Böttinger EP (2005) TGF-beta and epithelial-to-mesenchymal transitions. Oncogene 24: 5764-5774.

28. Harris RD, Steffes MW, Bilous RW, Sutherland DE, Mauer SM (1991) Global glomerular sclerosis and glomerular arteriolar hyalinosis in insulin dependen diabetes. Kidney Int 40: 107-114.

29. Tryggvason K, Patrakka J, Wartiovaara J (2006) Hereditary proteinuria syndromes and mechanisms of proteinuria. N Engl J Med 354: 1387-1401.

30. Wartiovaara J, Ofverstedt LG, Khoshnoodi J, Zhang J, Makela E, et al. (2004) Nephrin strands contribute to a porous slit diaphragm scaffold as revealed by electron tomography. J Clin Invest 114: 1475-1483.

31. Patrakka J, Tryggvason K (2007) Nephrin--a unique structural and signaling protein of the kidney filter. Trends Mol Med 13: 396-403.

32. Dobrinskikh E, Okamura K, Kopp JB, Doctor RB, Blaine J (2014) Human podocytes perform polarized, caveolae-dependent albumin endocytosis. Am J Physiol Renal Physiol 306: F941-951.

33. Russo LM, Sandoval RM, McKee M, Osicka TM, Collins AB, et al. (2007) The normal kidney filters nephrotic levels of albumin retrieved by proximal tubule cells: retrieval is disrupted in nephrotic states. Kidney Int 71: 504-513.

34. Tojo A, Endou H (1992) Intrarenal handling of proteins in rats using fractional micropuncture technique. Am J Physiol 263: F601-606.

35. Eppel GA, Osicka TM, Pratt LM, Jablonski P, Howden BO, et al. (1999) The return of glomerular-filtered albumin to the rat renal vein. Kidney Int 55: 1861 1870.

36. Cui S, Verroust PJ, Moestrup SK, Christensen El (1996) Megalin/gp330 mediates uptake of albumin in renal proximal tubule. Am J Physiol 271: F900907.

37. Birn H, Fyfe JC, Jacobsen C, Mounier F, Verroust PJ, et al. (2000) Cubilin is an albumin binding protein important for renal tubular albumin reabsorption. $\mathrm{J}$ Clin Invest 105: 1353-1361.

38. Koltun M, Comper WD (2004) Retention of albumin in the circulation is governed by saturable renal cell-mediated processes. Microcirculation 11: 351-360.

39. Koltun M, Nikolovski J, Strong K, Nikolic-Paterson D, Comper WD (2005) Mechanism of hypoalbuminemia in rodents. Am J Physiol Heart Circ Physio 288: H1604-1610.

40. Birn H, Christensen El (2006) Renal albumin absorption in physiology and pathology. Kidney Int 69: 440-449.

41. Hilliard LM, Osicka TM, Clavant SP, Robinson PJ, Nikolic-Paterson DJ, et al. (2006) Characterization of the urinary albumin degradation pathway in the isolated perfused rat kidney. J Lab Clin Med 147: 36-44.

42. Russo LM, Bakris GL, Comper WD (2002) Renal handling of albumin: a critical review of basic concepts and perspective. Am J Kidney Dis 39: 899-919.

43. Christensen El, Birn H (2002) Megalin and cubilin: multifunctional endocytic receptors. Nat Rev Mol Cell Biol 3: 256-266.

44. Thrailkill KM, Nimmo T, Bunn RC, Cockrell GE, Moreau CS, et al. (2009) Microalbuminuria in type 1 diabetes is associated with enhanced excretion of the endocytic multiligand receptors megalin and cubilin. Diabetes Care 32 : 1266-1268.
45. Zou Z, Chung B, Nguyen T, Mentone S, Thomson B, et al. (2004) Linking receptor-mediated endocytosis and cell signaling: evidence for regulated intramembrane proteolysis of megalin in proximal tubule. J Biol Chem 279 : 34302-34310.

46. Biemesderfer D (2006) Regulated intramembrane proteolysis of megalin linking urinary protein and gene regulation in proximal tubule? Kidney Int 69 1717-1721.

47. Sharma K, Ziyadeh FN (1994) The emerging role of transforming growth factorbeta in kidney diseases. Am J Physiol 266: F829-842.

48. Gekle M, Knaus P, Nielsen R, Mildenberger S, Freudinger R, et al. (2003) Transforming growth factor-beta1 reduces megalin- and cubilin-mediated endocytosis of albumin in proximal-tubule-derived opossum kidney cells. J Physiol 552: 471-481.

49. Gekle M, Mildenberger S, Freudinger R, Schwerdt G, Silbernagl S (1997) Albumin endocytosis in OK cells: dependence on actin and microtubules and regulation by protein kinases. Am J Physiol 272: F668-677.

50. Simister NE, Story CM, Chen HL, Hunt JS (1996) An IgG-transporting Fc receptor expressed in the syncytiotrophoblast of human placenta. Eur $J$ Immunol 26: 1527-1531.

51. Simister NE, Mostov KE (1989) An Fc receptor structurally related to MHC class I antigens. Nature 337: 184-187.

52. Borvak J, Richardson J, Medesan C, Antohe F, Radu C, et al. (1998) Functiona expression of the MHC class I-related receptor, FcRn, in endothelial cells of mice. Int Immunol 10: 1289-1298.

53. Blumberg RS, Koss T, Story CM, Barisani D, Polischuk J, et al. (1995) A major histocompatibility complex class I-related Fc receptor for $\operatorname{lgG}$ on rat hepatocytes. J Clin Invest 95: 2397-2402.

54. Haymann JP, Levraud JP, Bouet S, Kappes V, Hagège J, et al. (2000) Characterization and localization of the neonatal Fc receptor in adult human kidney. J Am Soc Nephrol 11: 632-639.

55. Tian Z, Sutton BJ, Zhang X (2014) Distribution of rat neonatal Fc receptor in the principal organs of neonatal and pubertal rats. J Recept Signal Transduct Res 34: 137-142.

56. Raghavan M, Bonagura VR, Morrison SL, Bjorkman PJ (1995) Analysis of the $\mathrm{pH}$ dependence of the neonatal $\mathrm{Fc}$ receptor/immunoglobulin $\mathrm{G}$ interaction using antibody and receptor variants. Biochemistry 34: 14649-14657.

57. Chaudhury C, Brooks CL, Carter DC, Robinson JM, Anderson CL (2006) Albumin binding to FcRn: distinct from the FcRn-lgG interaction. Biochemistry 45: 4983-4990.

58. Junghans RP, Anderson CL (1996) The protection receptor for IgG catabolism is the beta2-microglobulin-containing neonatal intestinal transport receptor Proc Natl Acad Sci U S A 93: 5512-5516.

59. Chaudhury C, Mehnaz S, Robinson JM, Hayton WL, Pearl DK, et al. (2003) The major histocompatibility complex-related Fc receptor for IgG (FcRn) binds albumin and prolongs its lifespan. J Exp Med 197: 315-322.

60. Sarav M, Wang Y, Hack BK, Chang A, Jensen M, et al. (2009) Renal FcRn reclaims albumin but facilitates elimination of IgG. J Am Soc Nephrol 20: 1941 1952

61. Tenten V, Menzel S, Kunter U, Sicking EM, van Roeyen CR, et al. (2013) Albumin is recycled from the primary urine by tubular transcytosis. J Am Soc Nephrol 24: 1966-1980.

62. Christensen El, Birn H (2013) Proteinuria: Tubular handling of albumin degradation or salvation? Nat Rev Nephrol 9: 700-702

63. Osicka TM, Houlihan CA, Chan JG, Jerums G, Comper WD (2000) Albuminuria in patients with type 1 diabetes is directly linked to changes in the lysosomemediated degradation of albumin during renal passage. Diabetes 49: 1579 1584.

64. Olbricht CJ, Geissinger B (1992) Renal hypertrophy in streptozotocin diabetic rats: role of proteolytic lysosomal enzymes. Kidney Int 41: 966-972.

65. Shechter P, Boner G, Rabkin R (1994) Tubular cell protein degradation in early diabetic renal hypertrophy. J Am Soc Nephrol 4: 1582-1587.

66. Russo LM, Osicka TM, Bonnet F, Jerums G, Comper WD (2002) Albuminuria in hypertension is linked to altered lysosomal activity and TGF-beta1 expression. Hypertension 39: 281-286. 
Citation: Peres GB, Michelacci YM (2015) The Role of Proximal Tubular Cells in the Early Stages of Diabetic Nephropathy. J Diabetes Metab 6: 551. doi:10.4172/2155-6156.1000551

67. Russo LM, Osicka TM, Brammar GC, Candido R, Jerums G, et al. (2003) Renal processing of albumin in diabetes and hypertension in rats: possible role of TGF-beta1. Am J Nephrol 23: 61-70.

68. Cadaval RA, Kohlman O, Michelacci YM (2000) Urinary excretion of glycosaminoglycans and albumin in experimental diabetes mellitus. Glycobiology 10: 185-192.

69. Torffvit O, Rippe B (1999) Size and charge selectivity of the glomerular filter in patients with insulin-dependent diabetes mellitus: urinary immunoglobulins and glycosaminoglycans. Nephron 83: 301-307.

70. Tencer J, Torffvit O, Bjornsson S, Thysell H, Grubb A, et al. (1997) Decreased excretion of glycosaminoglycans in patients with primary glomerular diseases. Clin Nephrol 48: 212-219.

71. de Lima CR, Aguiar JA, Michelacci YM (2005) Reduced urinary excretion of sulfated polysaccharides in diabetic rats. Biochim Biophys Acta 1741: 30-41.

72. Hansen C, Irmscher AK, Kuhlemann K, Beyer J, Kahaly G (1995) Insulindependent diabetes mellitus and glycosaminoglycans. Horm Metab Res 27: 555-558.
73. McAuliffe AV, Fisher EJ, McLennan SV, Yue DK, Turtle JR (1996) Urinary glycosaminoglycan excretion in NIDDM subjects: its relationship to albuminura. Diabet Med 13: 758-763.

74. Michelacci YM, Glashan RQ, Schor N (1989) Urinary excretion of glycosaminoglycans in normal and stone forming subjects. Kidney Int 36: $1022-$ 1028.

75. de Lima CR, Baccarin RY, Michelacci YM (2007) Reliability of 1,9-dimethymethylene blue tests in comparison to agarose gel electrophoresis for quantification of urinary glycosaminoglycans. Clin Chim Acta 378: 206-215.

76. Dietrich CP, McDuffie NM, Sampaio LO (1977) Identification of acidic mucopolysaccharides by agarose gel electrophoresis. J Chromatogr 130: 299304.

77. Aguiar JA, Lima CR, Berto AG, Michelacci YM (2003) An improved methodology to produce Flavobacterium heparinum chondroitinases, important instruments for diagnosis of diseases. Biotechnol Appl Biochem 37: 115-127. 